\title{
The Effect of Lockup on Management Earnings Forecasts Disclosure in French IPOs
}

\author{
Manel Allaya \\ Portsmouth Business School \\ University of Portsmouth, Portsmouth, UK \\ manel.allaya@myport.ac.uk \\ Narjess Toumi \\ IRG, Université de Paris Est, Créteil, France \\ toumi.narjess@yahoo.fr
}

\begin{abstract}
This study investigates the effect of lockup agreements on management earnings forecasts in initial public offering (IPO) prospectuses. Using a sample of 312 French firms that went public over the period 1997-2016, we find that IPOs with lockup agreements are more likely to disclose conservative earnings forecasts. In particular, we provide evidence that IPOs with more locked-up shares and those selecting longer lockup periods, have more accurate management earnings forecasts. In other words, managers of firms with a higher proportion of shares locked up and longer lockup agreements experience greater costs of nondiversification of idiosyncratic risk. They tend, thus, to provide more conservative and accurate forecasts to prevent costs arising from earnings forecast error. These results are robust to a number of sensitivity tests.
\end{abstract}

Keywords: Lockup; Initial public offerings; Management earnings forecasts; France 


\section{Introduction}

The finance literature recognizes that firms going public may face severe problems arising from information asymmetries between corporate insiders and investors during the initial public offering (IPO) process (see, e.g., Brav and Gompers, 2003; Courteau, 1995; Hughes, 1986). Previous studies show that these problems could be mitigated through underpricing (Allen and Faulhaber, 1989; Chemmanur, 1993; Ellul and Pagano, 2006), venture capital backing (Barry et al., 1990; Megginson and Weiss, 1991), prestigious underwriter backing (Carter and Manaster, 1990), and engaging reputable auditors (Titman and Trueman, 1986).

In the same vein, Hughes (1986) argues that voluntary disclosure plays a major role in reducing information asymmetries between issuers of IPOs and investors. Voluntary disclosure may represent a signaling mechanism that helps to discriminate between high and low quality firms. This author identifies management earnings forecasts in an IPO prospectus as a potential signal of firm quality. Moreover, a growing body of literature shows that lockup commitments can also serve as signaling devices to communicate the inherent quality of IPO firms (Bradley et al., 2001; Brav and Gompers, 2003; Courteau, 1995; Field and Hanka, 2001).

This study extends the growing body of literature on the signaling role of earnings forecast disclosures (Boubaker et al., 2017; Boubaker and Labégore, 2006; Chen and Firth, 1999; Cheng and Firth, 2000; Clarkson et al., 1992; Firth, 1998; Jog and MacConomy, 2003; Mak, 1996, among others) by examining the link between lockup agreements and earnings forecast disclosures in IPO prospectuses. Specifically, this paper addresses the following research question: Is there a relation between lockup characteristics and management earnings forecasts of IPO firms?

In lockup periods, the initial shareholders are prevented from selling their equity holdings. On NASDAQ, this time period is generally 180 days after publication of the IPO prospectus. However, in some cases, the period can span from 120 days to 1 year. Under certain conditions, if shareholders have beneficially owned their shares for less than two years, they submit to specific rules of the Securities and Exchange Commission (SEC), and in particular the SEC rule 144. This rule obliges them to make 
public their sales of shares and to fix quotas for these transfers so as not to dramatically affect stock prices.

Prior to January 2000, U.S. regulation imposed compulsory lockup agreements only for firms with a trading history of less than 3 years. Since January 2000, lockup contracts have not been mandatory and have become voluntary contracts in which both underwriters and issuers jointly determine the length of the lockup period. However, most firms adopt lockup agreements. In Germany, all pre-IPO shareholders that still own shares immediately after the firm locks up are subject to mandatory lockups. The initial shareholders must be locked up for 6 months with $100 \%$ of their shares. The French regulation provides companies with a choice between preserving their shares for 180 days for $100 \%$ of shares or for 360 days for $80 \%$ of shares. On the Second Market in France, there is no obligation on this matter, but certain companies make such commitments.

In this study, we use management earnings forecast data obtained from a sample of 312 prospectuses of French IPO firms over the period 1997-2016. We find that IPO firms with more shares to lock up, and those selecting longer lockup periods exhibit more conservative and accurate earnings forecasts. These results are robust to a battery of robustness checks, including, among others, the use of an alternative measure of earnings forecast errors and excluding the crisis years.

This study contributes to the literature in several ways. First, it is, to the best of our knowledge, among the first to examine the impact of lockup structure on IPO earnings forecast accuracy. Specifically, it investigates the relation between (i) length of lockup period, and (ii) percentage of equity locked up by shareholders on the credibility of earnings forecasts. Second, this research adds to the literature on the determinants of earnings forecast accuracy of newly-listed firms (e.g., Mak, 1994; Jaggi, 1997; Labégorre and Boubaker, 2005). Thus, it offers new evidence to the debate on the role of lockup agreements in IPO firms (e.g., Field and Hanka, 2001; Brav and Gompers, 2003).

Lockup agreements in France, like many other countries, prevent the initial shareholders of IPO companies from selling a specific amount of their equity for a 
contractually specified post-IPO period. Yet, newly listed firms in France, unlike in the United States, are allowed to present their earnings management forecasts in their prospectuses. This helps observing the relationship between lockup commitments and the quality of earnings forecast information in French IPO prospectuses.

The remainder of this paper proceeds as follows. Section 2 provides a brief institutional background description relating to lockup agreements and management earnings forecasts, and develops the main hypotheses. Section 3 describes the sample and defines the variables that are used in the analysis. Section 4 explains model specifications and discusses the results of the empirical analyses. Section 5 summarizes the paper and concludes.

\section{Background and hypotheses}

This section presents arguments suggesting a potential relation between lockups and IPO earnings forecasts. We first present a background description of the earnings forecasts in IPO prospectuses. We then provide a brief discussion of the structure of lockup contracts and develop our research hypotheses on how lockup agreements affect earnings forecasts in IPO prospectuses.

\subsection{Earnings forecast disclosure}

There is a large body of literature that focuses on management earnings forecasts due to the importance of the issue to investors (Wang et al., 2008; Abhayawansa and Abeysekera, 2009). Verrecchia (1983) claims that earnings forecasts play a significant signaling role since their publication provides investors with private information. In the same vein, Firth (1998) and Cheng and Firth (2000) demonstrate that disclosure of future earnings forecasts in the IPO prospectuses can be an important signal that helps in valuing firms. In fact, accurate forecasts mitigate information asymmetry between managers and investors and thus lower agency costs. Moreover, an IPO that provides accurate and reliable disclosure ensures lower information asymmetry and signals to outsiders that the firm is performing better than its peers (Miller, 2002).

The past three decades have witnessed a tremendous amount of academic research on IPOs. However, only a limited number of studies examine the determinants and accuracy of earnings forecasts in IPO prospectuses (e.g., Clarkson et 
al., 1989; Keasey and McGuiness, 1991; Firth and Smith, 1992; Firth et al., 1995; Jelic et al., 1998; Jog and McConomy, 2003; Mbuthia and Ward, 2003; Jaggi et al., 2006; Gounopoulos, 2011; Cormier et al., 2014). For instance, Keasey and McGuiness (1991) argue that including an earnings forecast in an IPO firm's prospectus depends upon its competitive position. Cormier et al. (2014) provide evidence that Canadian IPO firms with better governance are less likely to voluntarily disclose earnings forecasts in their prospectuses.

Moreover, previous studies on the accuracy of management earnings forecasts have reported mixed results. In this vein, Keasey and McGuiness (1991), Mbuthia and Ward (2003), and Jaggi et al. (2006) show that, on average, managers of IPO firms underestimate future earnings, while Firth and Smith (1992) and Hartnett and Romcke (2000) find negative average forecast errors, implying that managers of IPOs are optimistic in their earnings forecasts. Previous studies also show mixed results concerning the magnitude of absolute forecast errors. In this respect, Keasey and McGuinness (1991) and Jaggi (1997) find an average absolute forecast error of 11\% (in Singapore) and $12.79 \%$ (in Hong Kong), respectively. Other studies, however, report an average absolute forecast error of more than 80\% (e.g., Mak, 1989; Firth and Smith, 1992; Hartnett and Romcke, 2000).

\subsection{Lockup Agreements}

A large number of studies on IPOs examine the usefulness of lockup agreements. Brav and Gompers (2003) focus on the determinants of lockup period and consider three objectives to the use of lockup provisions: (i) a signaling mechanism to adverse selection problem; (ii) a commitment mechanism to moral hazard problem, and (iii) a rent extraction solution by powerful underwriters. These authors find evidence that lockup is an effective bonding device to overcome post-IPO moral hazard problems. However, they reject the hypothesis that lockup is a signaling device to an adverse selection problem. Brau et al. (2015) revisit this research area and find support for the concern that insiders signal their quality using longer lockup period since it is associated with larger asymmetric information and lower idiosyncratic risk. 
Many other studies were also carried to explain existing contradictory findings. Using a sample of 4,025 IPO firms between 1988 and 2006, Yung and Zender (2010) argue that IPO issues are likely to lock in their shares for a long period to alleviate both moral hazard and information asymmetry problems subsequent to the IPO. Karpoff et al. (2013) analyze 2,579 SEOs from 1996 to 2006 and treat lockup agreements as a contracting solution to asymmetric information phenomenon between insiders and new investors. Their results give support to the idea that lockups help to ensure the quality of an issue to the outside investors. In the same thread, Hoque (2014) examines a sample of UK IPOs listed between 1999 and 2006 and find evidence that lockups mitigate post-IPO moral hazard problems.

\subsection{Hypotheses development}

At the time of flotation, the quality of a particular firm is not apparent to outside investors. High quality firms may be concerned that potential investors would not be willing to pay a high price for their equity. Even if stock issues are, on average, fairly priced, high quality firms would still suffer from mispricing losses, because they are pooled with low firms. Hence, investors could be not abe to distinguish between high quality and low quality firms. In contrast, incumbent shareholders, who are involved in firm management, tend to have a better picture of the firm's prospects. They are more inclined to make optimistic forecasts to achieve a better offering price, but there are mechanisms that can mitigate this opportunistic behavior such as lockups. IPO lockup agreements give insiders motivation to provide truthful earnings forecasts and can guarantee investors that insiders remain committed to the firm until such time when more information concerning future earnings prospects are divulged to the public through news, analyst reports, and regulatory filings.

Following Leland and Pyle (1977), Courteau (1995) argues that the length of the lockup could serves as a mechanism to reduce asymmetric information, and thus as a signal of firm quality. This author claims that high quality IPOs signal their quality by implementing longer lockups. Moreover, Brav and Gompers (2003) document that lockup agreements play a significant role in alleviating moral hazard, signaling the quality of issuing firms and generating additional profit to the underwriter. 
In a similar vein, Chong and Ho (2007) claim that managers of firms with longer lockup periods are associated with longer periods of non-diversification of idiosyncratic risk. As a consequence, entrepreneurs tend to provide more conservative and more accurate forecasts to avoid the costs related to forecast errors, which can negatively affect the wealth of insiders and the long-term performance of the firm.

The foregoing reasoning leads to the following hypotheses:

H1: Firms with a higher percentage of shares locked up ussye more conservative earnings forecasts.

H2: Firms with longer lockup periods issue more conservative earnings forecasts.

\section{Data and variables}

This section describes data sources and sample selection procedure. It defines the variables used in our analysis and provides descriptive statistics.

\subsection{Sample selection and data sources}

Our initial sample consists of all French IPOs listed between 1997 and 2016 on the Second Marché and Nouveau Marché. We first eliminate financial corporations (SIC codes 6000-6999) and IPOs from utility industries (two-digit SIC code 49) because their earnings are highly regulated. We exclude foreign IPOs, transfers between market compartments, as well as issues listed on the over-the-counter market (Marché Libre). We also discard firms with missing financial data. This process yields a final sample of 312 IPOs. Financial and specific information concerning IPOs are gathered from IPO prospectuses, annual reports published on firm websites and the website of the Financial Market Authority ${ }^{1}$.

Table 1 presents the distribution by year (Panel A) and by industry (Panel B) of the full sample as well as the forecasters' subsample. In Panel A, we observe a significant decrease in the proportion of forecasters over the 2005-2016 period (less than $40 \%$ ) compared to the previous period. This finding could be due to the reform of the Paris Stock Exchange implemented on 21 February 2005. Panel B of Table 1

\footnotetext{
${ }^{1}$ Autorité des Marchés Financier is the French equivalent of the SEC..
} 
reports the distribution of our sample firms by industry ${ }^{2}$. The two industries that have a higher percentage of IPOs are services (41.91\%) and consumer durables $(18.32 \%)$. Note also that $81.48 \%$ (79.41\%) of IPOs in the leisure (textile \& trade) industry provide an earnings forecast in their prospectuses, while only $47.50 \%$ of the basic industry firms publish their earnings forecasts during the IPO. Table 2 presents the distribution of lockup periods. The mean (median) lockup lengths for forecasters are 14.2 (12.0).

[Insert Table 1 about here]

[Insert Table 2 about here]

\subsection{Regression variables}

Appendix A summarizes the definitions and measurement of all variables used in the analysis.

\subsubsection{Dependent variable: Earnings forecast error}

Following Chin et al. (2006), we compute earnings forecast errors as the difference between forecasted earnings and actual earnings, all scaled by total assets. Earnings are profits after tax and before extraordinary items. We define forecast error as:

$$
F E_{i t}=\frac{\left(F P_{i t}-A P_{i t}\right)}{\text { Total assets }} \times 100
$$

where, FE is forecast error for the IPO; AP is the actual earnings of the IPO; and FP is the earnings forecast as provided in the IPO prospectus. The mean forecast error reflects the degree of bias in forecasting. If the forecasted earnings are lower than actual earnings, FE is negative, implying a pessimistic (conservative) bias in managers' forecasts, while a positive FE indicates an optimistic bias.

\footnotetext{
2 We classify the industry of our sample firms using the Campbell (1996) industry classification. When we rerun the regressions by including industry variables, our findings remain qualitatively unchanged.
} 
To proxy for the magnitude of forecast error, we use absolute forecast error (AFE), measured as follows:

$$
A F E_{i t}=\left|F E_{i t}\right|
$$

\subsubsection{Variables of interest: Lockup agreements}

We determine whether a firm has a lockup agreement by investigating IPO prospectuses. If it has an agreement, we check whether it is a voluntary contract and collect the expiration date of the lockup and the fraction of shares subject to lockup. We consider two lockup-related variables to proxy for the presence of voluntary lockup agreements and the characteristics of these contracts: (i) LOCKUP_PER is the percentage of shares subject to lockup; and (ii) LOCKUP_LENGTH is the number of

months after the listing date during which the insiders agree not to sell a specified number of their shares.

\subsubsection{Control variables}

The literature identifies a set of factors that are expected to affect earnings forecast accuracy. These control variables included in the model are firm size, firm age, horizon forecast, financial leverage, ownership, and stock exchange.

Size is proxied using the natural logarithm of total assets in thousands of euros. It is argued that earnings forecast errors depend on firm size. Previous research shows that it is easier for large firms to generate credible forecasts, since they have more control of their market settings and more influence over the level of their profits (Chan et al., 1996; Chen et al., 2001). Also, large firms are usually more diversified, able to cope with economic fluctuations, and so are able to contend with unpredicted financial events (Firth and Smith, 1992; Hagerman and Ruland, 1997). Other studies document that large-sized firms benefit from more available information, more detailed disclosure strategies, and better predicting systems, since they are followed by more prestigious analysts (Mefteh-Wali et al., 2012).

HORIZON (Horizon forecast) is defined as the number of months between the date of issue of the prospectus and the first post-listing year-end of the company. Under certain circumstances, the horizon forecast may become a potential proxy for forecast 
credibility. It has been argued that forecasts with a longer time horizon may make forecasting of the firm's earnings more complicated. Indeed, the longer the time lapse between the release of the forecast and the realization of the forecast, the more the firm will be associated with uncertainty (Jaggi, 1997). Therefore, short-term earnings are intrinsically easier to predict (Firth et al., 1995). Furthermore, Brown et al. (2000) suggest that the length of the forecast horizon is the most important determinant of earnings predictability.

LNAGE is proxied by the natural logarithm of the number of years between establishment of the firm and the IPO date. Earlier studies show evidence that age is negatively associated with forecast error. In fact, mature companies have longer experience, historical bases and are in a better position to control their market situation (Hartnett and Rômcke, 2000). However, firms that went public just a few years after their creation suffer from comparatively lower level of appreciation, so that they tend to provide a more optimistic picture of their future performance prospects (Firth et al., 1995; Jaggi, 1997).

LEVERAGE (Financial Leverage) is the ratio of total liabilities to total assets. The financial leverage of a company indicates the fraction of firm profit expensed as interest. In fact, firms with higher leverage face higher levels of debt, and so more risk factors (Jaggi, 1997; Chen et al., 2001). Eddy and Seifert (1992) claim that higher leverage can cause greater fluctuation in earnings and therefore make the earnings forecast process more uncertain and difficult. Thus, firms with important levels of debt are likely to experience more volatile earnings.

OWNERSHIP controls for the equity stock held by all inside board members. Several studies focus on ownership retained and its impact on management earnings forecasts. Most of this research emphasizes that forecast quality might be affected by the fraction of shares retained by insiders (Ajinkya at al., 2005). Firms with higher retained ownership face fewer information asymmetry problems (Leland and Pyle, 1977), hence, they are likely to provide conservative earnings forecasts. In other words, firms with higher retained ownership have incentives to signal their quality by 
providing conservative forecasts. As a result, forecast accuracy increases in the case of high insider ownership.

NM (Nouveau Marché) is a dummy variable that equals 1 if a firm is listed on the Nouveau Marché, and zero otherwise. Prior French studies consider two distinct exchanges where most companies go public: the Second Marché and Nouveau Marché. While the Second Marché is designed to serve well-known and large companies, the Nouveau Marché was created to attract smaller-size offerings with a short history, mainly in high-technology industries. It follows then that firms undertaking an IPO on the Nouveau Marché are riskier than those choosing the Second Marché for listing. Furthermore, IPOs on the Nouveau Marché are required to generate forecast financial statements of at least a three-year history, but there are no such requirements for Second Marché offerings. According to Degeorge and Derrien (2001), managers are less conservative for Nouveau Marché IPOs, which is explained by the relationship between ex ante uncertainty and manager optimism.

\subsection{Descriptive statistics}

Table 3 provides summary statistics of the variables used in our analysis. On average, our sample IPOs lock up around $80 \%$ (median, $81.56 \%$ ) of their post-IPO insiders' shares with a mean (median) lockup period of about 14 months (12 months). The forecast horizon ranges from less than two weeks (0.3) to slightly more than one year (12.36 months), with an average of 6.30 months. Furthermore, the sample includes newly founded (minimum age of 2 months) and old (maximum age of 115 years) firms, with an average age of more than 14 years. It also includes low-leveraged (minimum of $3.52 \%$ ) and highly leveraged (maximum of 94.23) firms, with an average leverage ratio of $57.34 \%$. In addition, pre-IPO insiders retain, on average, about $61.60 \%$ of their firms' shares. Moreover, $28.92 \%$ of the sample firms are listed on the Nouveau Marché. Panel B of Table 3 depicts Pearson (above the diagonal) and Spearman (below the diagonal) correlations between the regressors. The correlation coefficients between the independent variables used in the same specification are low, which provides some assurance that multicollinearity is not a serious problem. In addition, we calculate the 
variance inflation factors (VIFs) for each specification as an additional test for multicollinearity. The VIFs do not exceed the critical value of 10 (Neter et al., 1989), with a maximum value of 2.2, implying that multicollinearity does not appear to pose a serious problem.

\section{[Insert Table 3 about here]}

Table 4 presents the distribution of forecast errors. As shown, 20.19\% (22.76\%) of forecast errors are less (greater) than $-10 \%(10 \%)$ of the forecast errors. Moreover, $75.32 \%$ of the earnings forecast are positive indicating that there is optimistic bias in the forecasts issued by the IPO firms.

\section{Empirical Analysis}

This section details the empirical model, presents and discusses the main results, and sets forth several sensitivity tests.

\subsection{Empirical model}

To empirically test our hypotheses, we estimate the following cross-sectional model: FORECAST $=\beta_{0}+\beta_{1} L O C K U P+\beta_{2} S I Z E+\beta_{3} H O R I Z O N+\beta_{4} L N A G E+\beta_{5} L E V E R A G E$

$+\beta_{6}$ OWNERSHIP $+\beta_{7}$ NM + Industry dummies + Year dummies

The dependent variable is the earnings forecast error, which indicates the difference between the earnings forecast provided in the IPO prospectus and actual earnings, deflated by total assets. The key variable of interest is LOCKUP, which is predicted to be negative. Control variables are SIZE, HORIZON, LNAGE, LEVERAGE, OWNERSHIP and NM.

\subsection{The voluntary earnings forecast disclosure decision}

In this subsection, we examine the determinants that affect a firm's choice to issue an earnings forecast. Thus, we run a logistic regression that explains the decision of IPO firms to disclose voluntary earnings forecasts. In this case, the dependent variable FORECAST is a dummy variable that takes the value 1 when the firm provides an 
earnings forecast in its prospectus, and 0 otherwise. We use the same set of independent variables as in Equation 3.

Table 5 reports the results of the logistic regression of FORECAST. First, we find that larger IPO firms are more likely to disclose an earnings forecast in their prospectuses. This finding implies that larger firms have more control of their market setting, making it easier to forecast (Cox, 1985; Firth and Smith, 1992; Brown et al., 2000; Chen et al., 2001). Managers of old firms are also more inclined to publish earnings forecasts in their IPO prospectuses as they have longer business experience and better capabilities to control the financial situation. In addition, OWNERSHIP appears to be positively related to voluntary disclosure of earnings forecasts. This result suggests that firms with higher retained ownership are more likely to forecast their profits, since they face fewer information asymmetry problems (Leland and Pyle, 1977). Because of differing listing requirements, firms listed in the Nouveau Marché are more likely to disclose their earnings forecasts in their prospectuses. We also find that firms in industrial sectors are more likely to issue forecasts compared to firms in other industries. The coefficient estimates of the other explanatory variables show the expected signs, but are not statistically significant.

\section{[Insert Table 5 about here]}

\subsection{Evidence on the impact of lockup on earnings forecast errors}

Tables 5 and 6 report regression results of Equation (3) using, respectively, earnings forecast bias (FE) and earnings forecast accuracy (AFE) as dependent variables. These tables present the results from ordinary least squares regressions for our sample IPOs over the 1997-2016 period. Each column in the tables represents a variant of the regression. In each specification, we consider two groups of independent variables. First, our main concern is the coefficient estimates for the lockup-related variables. Thus, we include in the first specification the variable $L P \_P E R$, which proxies for lockup agreement. This variable is equal to the percentage of shares subject to lockup. In the second specification, we use the variable $L P \_L E N G T H$, which indicates the lockup period. The second group consists of firm-specific characteristics 
variables that have been shown in previous literature to affect earnings forecasts, namely, SIZE, HORIZON, LNAGE, LEVERAGE, OWNERSHIP and NM.

Table 6 provides empirical results for forecast bias. In all specifications, the VIFs are less than 2, indicating the absence of multicollinearity problems. The first specification includes the variable $L P \_P E R$, which equals the fraction of shares subject to lockup. The results show that the coefficient of this variable exerts a negative and significant impact (at the 1\% level) on forecast errors. This finding indicates that IPOs of companies with a higher proportion of shares locked up experience small earnings forecast errors (H1). In the second specification, we use the variable LP_LENGTH, which is equal to the length of the lockup period in months. As expected, the coefficient of this variable is negative and statistically significant at the $1 \%$ level. This finding implies that longer lockup agreements are associated with smaller earnings forecast errors, which is consistent with H2. In sum, these findings provide support for our main hypotheses, which state that IPO firms with higher shares locked up and longer lockup period might be not able to diversify their idiosyncratic risk, thus providing more conservative forecasts.

With regard to the control variables, we report negative and highly significant coefficients for SIZE, showing that larger firms provide more conservative forecasts. Moreover, management in industrial-sector firms have incentive to provide conservative earnings forecasts. It seems that there is no difference in terms of forecast bias between firms that are listed on the Nouveau Marché and those on the Second Marché. The coefficient of NM is positive but statistically non-significant. Firm age, leverage and forecast horizon do not also seem to affect management earnings forecast bias.

\section{[Insert Table 6 about here]}

We now rerun our main regressions from Table 6 using earnings forecast accuracy $(A F E)$ as a dependent variable rather than earnings forecast bias (FE). The results are reported in Table 7 . We find that our previous results on the lockup variables remain qualitatively the same. In all specifications, the coefficients of the 
variables $L P \_P E R$ and $L P \_L E N G T H$ are negative and statistically significant at the $1 \%$ level. These findings indicate that lockup agreements are associated with more accurate earnings forecasts. In other words, these results provide support for our hypotheses, which state that IPO firms with voluntary lockup agreements should have less absolute earnings forecast errors than other ones. This is consistent with the view that insiders of IPO firms with contractual lockup agreements, those selecting more shares to lockup or longer lockup periods have greater incentives to provide truthful earnings forecasts, since they are more exposed to more idiosyncratic risk.

Among the control variables included in the model, coefficient estimates for SIZE and NM confirm the predicted sign and are statistically significant. In particular, the coefficient of SIZE is consistent with previous research suggesting that larger companies are associated with a lower level of earnings forecast error, since they are typically more diversified and have more control over their market settings (Clarkson, 2000; Chen et al., 2001). Moreover, firms listed on the Nouveau Marché tend to achieve a significantly higher level of credibility. Specification (1) shows that the coefficient estimate on OWNERSHIP is negative and statistically significant at the $5 \%$ level. This suggests that the higher the percentage of shares retained by insiders, the more accurate are the earnings forecasts.

\section{[Insert Table 7 about here]}

\subsection{Sensitivity tests}

To check the robustness of our main findings, several supplementary tests are conducted. First, we carry out an additional regression analysis taking in account a possible selection bias since firm's characteristics can distinguish firms that publish earnings forecasts from others. Therefore, we use Heckman's (1970) two stage procedure to correct for this possible bias. In the first stage, we explain the decision to voluntarily publish earnings forecasts in the IPO prospectus. In the second stage, we explore the determinants of absolute forecast errors after correcting the sample selection bias using the inverse Mills ratio. The results are reported in Table 8.

In the first stage, we use probit regression model where the dependent variable, denoted FORECAST, is a dummy variable taking the value one if the IPO manager has 
published earnings forecast results in the prospectus. As shown in the first-stage regression in Table 8, lockup length, firm size and insiders' ownership are associated with higher likelihood of disclosing earnings forecast in the prospectus. The second stage regression investigates the impact of lockup percentage (first specification) and lockup length (second specification) on the absolute forecast errors after correcting potential sample selection bias. As reported in Table 8, the coefficients of LP_PER and LP_LENGTH are negatively and significantly related to the absolute forecast errors, implying that managers of firms with lockup agreement (longer lockup period and larger IPO share lockup) are more likely to provide accurate earnings forecast. The results support our hypotheses (H1) and (H2). Regarding control variables, we find a significantly negative relationship between firm size and absolute forecast errors which indicates that large firms tend to publish more accurate forecasts. The estimated coefficients of insiders' ownership and Nouveau Marché are significantly positive, showing that firms with higher insider ownership and those listed in the Nouveau Marché are less likely to provide accurate predictions in their prospectuses. Generally, all the results are consistent with the baseline findings.

\section{[Insert Table 8 about here]}

To further strengthen the validity of our main results, we test whether our conclusions are robust to (i) using an alternative proxy for earnings forecast errors, (ii) modifying measurement of the lockup variable, (iii) excluding crisis years and (iv) dropping service-industry firms. All results are presented in Table 9.3

In the first specification of Table 9, we consider an alternative variable, square forecast error (SQFE), which proxies for earnings forecasts. The squared forecast error is calculated using the square of the forecast errors, which gives more weight to high errors. According to Firth and Smith (1992), SQFE better models the loss to investors due to an erroneous forecast. Specification (2) uses the natural logarithm of the lockup

\footnotetext{
${ }^{3}$ For sake of brevity, we only include LP_LENGHT. Columns 2-4 (Table 9) report the results of regressions using absolute forecast error as the dependent variable. The results remain qualitatively similar when we use LOCKUP_PER as an alternative proxy for the importance of the lockup agreement.
} 
period as an alternative measurement of the lockup variable. Specification (2) excludes firms that were listed during the global financial crisis of 2007-2008 from the sample. In the last specification, we drop firms operating in the services industry from the analysis as the results may be driven by firms from this particular industry due to their importance in our sample. Overall, none of these variations qualitatively affects our results.

\section{[Insert Table 9 about here]}

\section{Conclusion}

A large body of literature focuses on the quality of earnings forecasts in IPO prospectuses. This literature shows that many factors could affect IPO earnings forecast errors, such as corporate governance (Cormier et al., 2014) and underwriter reputation (Jelic et al., 2001). However, no attention has been given to the role of lockups in determining the accuracy of management earnings forecasts in IPOs.

This study improves our understanding of how lockup agreements affect the quality of management earnings forecasts. We hypothesize that IPOs with higher percentage of shares subject to lockup and longer lockup period experience more conservative and accurate earnings forecasts. Using a sample of 312 forecasts of French IPOs listed between 1997 and 2016, our empirical results suggest that lockup percentage and lockup period are positively associated with more accurate earnings forecasts. The underlying reasoning is consistent with Chong and Ho (2007), who predict that longer lockup periods correspond to longer periods of non-diversification of idiosyncratic risk. Insiders of firms selecting more shares to lockup and longer lockup periods tend to provide credible earnings forecasts because they are more exposed to idiosyncratic risk. Our findings are robust to a battery of robustness tests including the use of alternative proxies for earning forecast errors and lockup contacts, excluding the crisis period and discarding service-industry firms. 


\section{References}

Abhayawansa, S., and Abeysekera, I. 2009. "Intellectual capital disclosure from sell-side analyst perspective. " Journal of Intellectual Capital 10(2): 294-306.

Allen, F., and Faulhaber, G.R. 1989."Signalling by underpricing in the IPO market." Journal of Financial Economics 23(2): 303-323.

Barry, C. B., Muscarella, C. J., Peavy, J. W., and Vetsuypens, M. R. 1990."The role of venture capital in the creation of public companies: Evidence from the going-public process. "Journal of Financial Economics 27(2): 447-471.

Boubaker, S., Gounoupolos, D., Kallias, A., and Kallias, K., 2017, "Management Earnings Forecasts and IPO Performance: Evidence of a Regime Change", Review of Quantitative Accounting and Finance, 48 (4): 1083-1121.

Boubaker, S. and Labégorre, F., 2006, "Les Déterminants de la Précision des Prévisions de Résultat Publiées dans les Prospectus d'Introduction au Second Marché (1994-2000) ", Comptabilité, Contrôle et Audit, 12(2) : 143-166.

Bradley, D. J., Jordan, B. D., Yi, H. C., and Roten, I. C. 2001. "Venture capital and IPO lockup expiration: An empirical analysis. " Journal of Financial Research 24(4): 465-493.

Brav, A., and Gompers, P. A. 1997."Myth or reality? The long-run underperformance of initial public offerings: evidence from venture and non-venture capital-backed companies." Journal of Finance 52(5): 1791-1821.

Brav, A., and Gompers, P. A. 2003. "The role of lockups in initial public offerings. " Review of Financial Studies, 16(1): 1-29.

Brown, P., and Clarke, A., How, J., and Lim, K. 2000."The accuracy of management dividend forecasts in Australia." Pacific-Basin Finance Journal 8(3-4): 309-331.

Carter, R., and Manaster, S. 1990. "Initial public offerings and underwriter reputation. " Journal of Finance 45(4): 1045-1067.

Chin, C. L., Kleinman, G., Lee, P., and Lin, M. F. 2006."Corporate ownership structure and accuracy and bias of mandatory earnings forecast: Evidence from Taiwan." Journal of International Accounting Research 5(2): 41-62.

Cormier, D., Lapointe-Antunes, P., and McConomy, B. J. 2014."Forecasts in IPO prospectuses: The effect of corporate governance on earnings management. "Journal of Business Finance and Accounting 41(1-2): 100-127.

Chan, A., Cora, S., Millie, T., Wong, D., and Chan, R. 1996."Possible factors of the accuracy of prospectus earnings forecasts in Hong Kong." International Journal of Accounting 31: 381-398.

Chemmanur, T. J. 1993."The pricing of initial public offerings: A dynamic model with information production." Journal of Finance 48(1): 285-304. 
Chen, G., and Firth, M. 1999."The accuracy of profit forecasts and their roles and associations with IPO firm valuations." Journal of International Financial Management and Accounting 10(3): 202-226.

Chen, G., and Firth, M., Krishnan, G.V. 2001."Earnings forecast errors in IPO prospectuses and their associations with initial stock returns." Journal of Multinational Financial Management 11(2): 225-240.

Cheng, T. Y., and Firth, M. 2000."An empirical analysis of the bias and rationality of profit forecasts published in new issue prospectuses." Journal of Business Finance and Accounting 27(34): 423-446.

Chong, B. S., and Ho, K. M. 2007."Lockup and voluntary earnings forecast disclosure in IPOs." Financial Management 36(3): 63-80.

Clarkson, P., Donoth, A., Richardson, G., and Sefcik, S. 1989."Assessing forecast-an analysis." CGA Magazine, 47-52.

Clarkson, P., and Donoth, A., Richardson, and G., Sefcik, S. E. 1992."The voluntary inclusion of earnings forecasts in IPO prospectuses." Contemporary Accounting Research 8(2):601-626.

Clarkson, P.M. 2000. "Auditor Quality and the Accuracy of Management Earnings Forecasts.

" Contemporary Accounting Research 17(4):595-622.

Courteau, L. 1995."Under-diversification and retention commitments in IPOs." Journal of Financial and Quantitative Analysis 30(4): 487-517.

Cox, C. 1985."Further evidence on the representativeness of management earning forecasts." Accounting Review 60: 692-701.

Eddy, A., and Seifert, B. 1992. "An examination of hypothesis concerning earning forecasts errors." Quarterly Journal of Business and Economics 31: 22-37.

Ellul, A., and Pagano, M. 2006."IPO underpricing and after-market liquidity." Review of Financial Studies 19(2): 381-421.

Field, L. C., and Hanka, G. 2001. "The expiration of IPO share lockups." Journal of Finance 56(2): 471-500.

Firth, M. 1998."IPO profits forecasts and their role in signalling firm value and explaining postlisting returns." Applied Financial Economics 8: 29-39.

Firth, M., and Kwok, B., Liau-Tan, C.K., and Yeo, G.H. 1995."Accuracy of profit forecasts in IPO prospectus." Accounting and Business Review 2: 55-83.

Firth, M., and Smith, A. 1992."The accuracy of profits forecasts in initial public offerings prospectuses." Accounting and Business Research 22: 239-247. 
Gounopoulos, D. 2011."Associations between management forecast accuracy and pricing of IPOs in Athens Stock Exchange." Multinational Finance Journal 15(3-4): 235-272.

Gounopoulos, D., Kraft, A., and Skinner, F. 2013."Voluntary vs. Mandatory Management Earnings Forecasts in IPOs."

Hartnett, N., and Romcke, J. 2000."The predictability of management forecast error: A study of Australian IPO disclosure." Multinational Finance Journal 4: 101-132.

Hughes, P.J. 1986. "Signalling by direct disclosure under asymmetric information. " Journal of Accounting and Economics 8: 119-142.

Jaggi, B. 1997."Accuracy of forecast information disclosed in the IPO prospectuses of Hong Kong companies." International Journal of Accounting 32(3): 301-319.

Jaggi, B., and Chin, C., Lin, H., and Lee, P. 2006."Earnings forecast disclosure regulation and earnings management: evidence from Taiwan IPO firms " Review of Quantitative Finance and Accounting 26(3): 275-299.

Jelic, R., and Saadouni, B., and Briston, R. 1998. "The accuracy of earnings forecast in IPO prospectuses on the Kuala Lumpur Stock Exchange 1984-1995." Accounting and Business Research 29: 57-72.

Jelic R., Saadouni B., and Briston R. 2001. "Performance of Malaysian IPOs: Underwriters Reputation and Management Earnings Forecasts." Pacific-Basin Finance Journal 9: 457-186.

Jog, V., and McConomy, B. 2003."Voluntary disclosures of management earnings forecast in IPOs and the impact on underpricing and post - issue return performance." Journal of Business Finance and Accounting 30(1-2): 125-167.

Keasey, K., and McGuiness, P. 1991."Prospectus earning forecasts and the pricing of new issue on the unlisted securities market."Accounting and Business Research 21: 133-145.

Labégorre, F. and Boubaker, S., 2005, "Publication volontaire de prévisions et rentabilités initiales: le cas des admissions à la cote du SM (94-00)", Banque et Marchés, 77 : 35-46.

Lelalnd H., and Pyle D. 1977."Informational Asymmetries, Financial Structure, and Financial Intermediation." Journal of Finance 32(2): 371-387.

Mak, Y. 1989."The determinants of accuracy of management earning forecast: A New Zealand study." International Journal of Accounting 24: 267-280.

Mak, Y. 1994."The voluntary review of earnings forecasts disclosed in IPO prospectuses." Journal of Accounting and Public Policy 13(2): 141-158.

Mak, Y. T. 1996."Forecast disclosure by initial public offering firms in a low-litigation environment. " Journal of Accounting and Public Policy 15(2): 111-136. 
Mbuthia, E., and Ward, M. 2003."The reliability of pre-listing earnings forecasts on the JSE." Investment Analysts Journal 32(57): 33-40.

Megginson, W. L., and Weiss, K. A. 1991."Venture capitalist certification in initial public offerings. " Journal of Finance 879-903.

Miller, G. S. 2002."Earnings performance and discretionary disclosure." Journal of Accounting Research 40(1): 173-204.

Neter, J., Wasserman, W., and Kutner, M. H. 1989. "Applied linear regression models."

Titman, S., and Trueman, B. 1986."Information quality and the valuation of the new issues."Journal of Accounting and Economics 8: 159-172.

Verrecchia, R. E. 1983."Discretionary disclosure." Journal of Accounting and Economics 5: 179194.

Wang, K., Sewon, O., and Claiborne, M. C. 2008."Determinants and consequences of voluntary disclosure in an emerging market: Evidence from China. " Journal of International Accounting, Auditing and Taxation 17(1) : 14-30. 
Appendix A

Variable, Definitions, and Sources

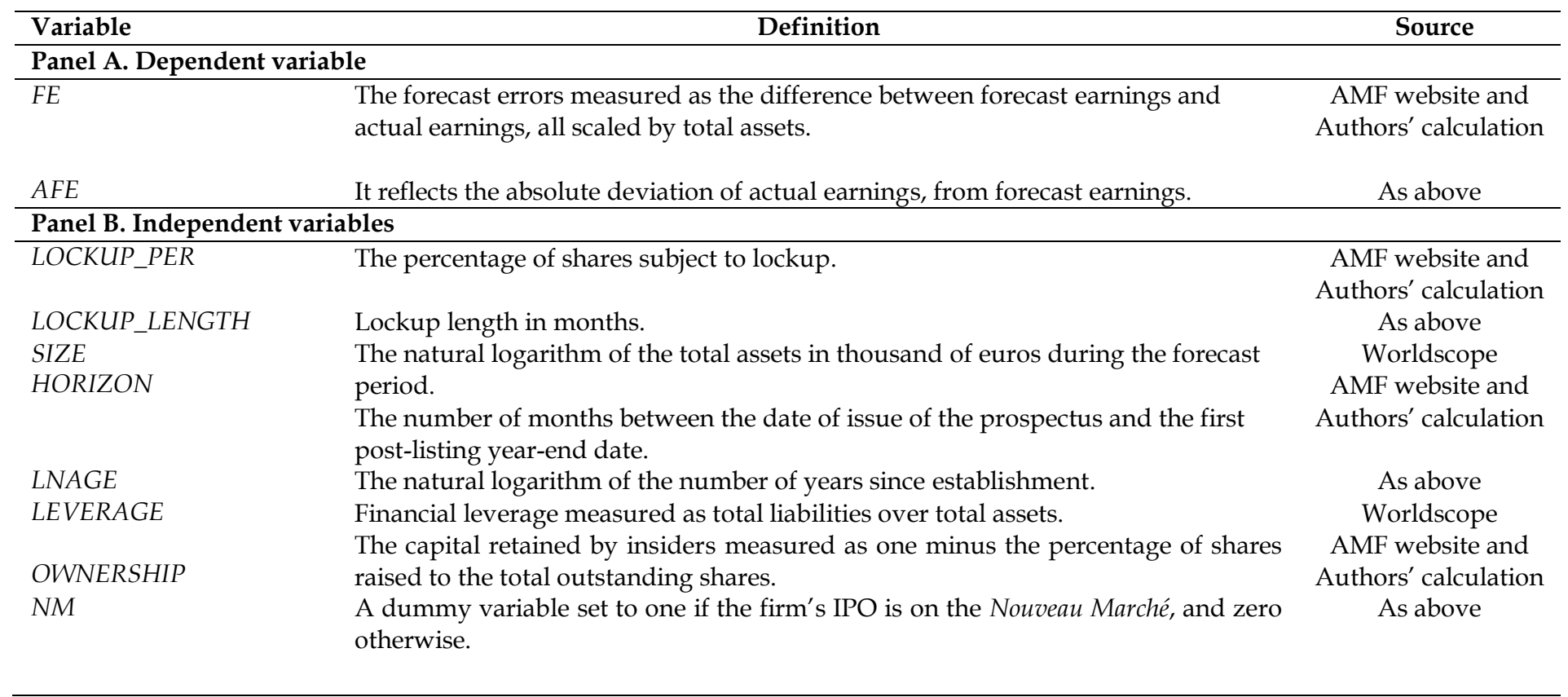


Table 1. Sample distribution by year and by industry

\begin{tabular}{|c|c|c|c|c|}
\hline & \multicolumn{2}{|c|}{ Full Sample } & \multicolumn{2}{|r|}{ Forecasters } \\
\hline & Number & Percentage & Number & $\begin{array}{c}\text { Percentage of } \\
\text { Raw Total }\end{array}$ \\
\hline \multicolumn{5}{|c|}{ Panel A : Distribution by Year } \\
\hline 1997 & 51 & 9.94 & 42 & 82.35 \\
\hline 1998 & 105 & 20.47 & 80 & 76.19 \\
\hline 1999 & 59 & 11.50 & 54 & 91.53 \\
\hline 2000 & 59 & 11.50 & 58 & 98.31 \\
\hline 2001 & 14 & 2.73 & 14 & 100 \\
\hline 2002 & 8 & 1.56 & 7 & 87.50 \\
\hline 2003 & 0 & 0.00 & 0 & 0 \\
\hline 2004 & 8 & 1.56 & 6 & 75.00 \\
\hline 2005 & 22 & 4.29 & 8 & 36.36 \\
\hline 2006 & 55 & 10.72 & 15 & 27.27 \\
\hline 2007 & 23 & 4.48 & 6 & 26.09 \\
\hline 2008 & 4 & 0.78 & 1 & 25.00 \\
\hline 2009 & 2 & 0.39 & 0 & 0.00 \\
\hline 2010 & 14 & 2.73 & 4 & 28.57 \\
\hline 2011 & 15 & 2.92 & 6 & 40.00 \\
\hline 2012 & 9 & 1.75 & 1 & 11.11 \\
\hline 2013 & 11 & 2.14 & 1 & 9.09 \\
\hline 2014 & 19 & 3.70 & 3 & 15.59 \\
\hline 2015 & 23 & 4.48 & 4 & 17.39 \\
\hline 2016 & 12 & 2.34 & 2 & 16.67 \\
\hline Total & 513 & 100 & 312 & 60.82 \\
\hline \multicolumn{5}{|c|}{ Panel B : Distribution by Industry } \\
\hline Petroleum & 4 & 0.78 & 2 & 50.00 \\
\hline Consumer durables & 94 & 18.32 & 52 & 55.32 \\
\hline Basic industry & 40 & 7.80 & 19 & 47.50 \\
\hline Food and tobacco & 12 & 2.34 & 9 & 75.00 \\
\hline Construction & 11 & 2.14 & 6 & 54.55 \\
\hline Capital goods & 55 & 10.72 & 32 & 58.18 \\
\hline Transportation & 21 & 4.09 & 11 & 52.38 \\
\hline Textiles \& trades & 34 & 6.63 & 27 & 79.41 \\
\hline Services & 215 & 41.91 & 132 & 61.04 \\
\hline Leisure & 27 & 5.26 & 22 & 81.48 \\
\hline Total & 513 & 100 & 312 & 60.82 \\
\hline
\end{tabular}

Notes: This table presents the sample distributions by year (Panel A) and by industry (Panel B). The sample consists of 513 French IPOs subsequently listed on the Euronext from January 1997 to December 2016. 
Table 2. Distribution of lockup lengths

\begin{tabular}{lcc}
\hline Lockup Period & Number & Percentage \\
& & 10.89 \\
6 Months & 34 & 70.19 \\
12 Months & 219 & 18.92 \\
$>12$ months & 59 & 100 \\
Total & 312 & 14.2 \\
Mean (Months) & & 12.0 \\
Median (Months) & & \\
\hline Notes: This table presents the distribution of lockup period for the forecasters.
\end{tabular}


Table 3. Summary statistics and correlations

\begin{tabular}{|c|c|c|c|c|c|c|c|c|}
\hline Variables & LOCKUP_PER & LOCKUP_LENGTH & SIZE & HORIZON & LNAGE & LEVERAGE & OWNERSHIP & $N M$ \\
\hline Minimum & 10.000 & 3.000 & 8.457 & 0.300 & -1.833 & 0.035 & 0.000 & 0.000 \\
\hline Median & 81.558 & 12.000 & 10.667 & 6.161 & 2.303 & 0.546 & 0.627 & 0.000 \\
\hline Mean & 80 & 14.238 & 12.076 & 6.300 & 2.671 & 0.573 & 0.616 & 0.289 \\
\hline Maximum & 100.000 & 36.000 & 23.592 & 12.367 & 4.745 & 0.942 & 0.964 & 1.000 \\
\hline Standard deviation & 8.845 & 7.896 & 3.264 & 2.528 & 2.291 & 0.175 & 0.191 & 0.458 \\
\hline
\end{tabular}

\begin{tabular}{|c|c|c|c|c|c|c|c|c|}
\hline Variables & 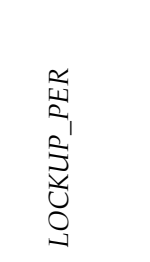 & 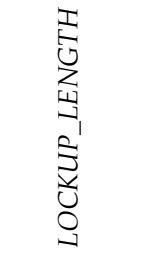 & $\underset{\omega}{N}$ & \begin{tabular}{l}
$z$ \\
0 \\
$N$ \\
\multirow{2}{0}{} \\
0
\end{tabular} & 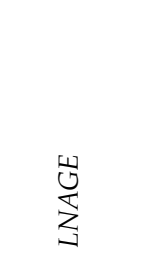 & 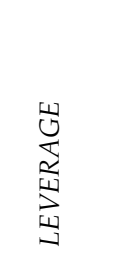 & 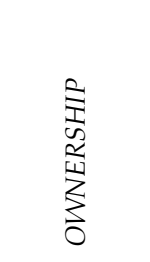 & $\sum$ \\
\hline LOCKUP_PER & 1.000 & $-0.528^{* * * *}$ & $0.086^{*}$ & -0.035 & $-0.097^{* *}$ & $-0.084^{*}$ & $-0.110^{* *}$ & $0.097^{* *}$ \\
\hline LOCKUP_LENGTH & $-0.227^{* * *}$ & 1.000 & -0.075 & -0.034 & -0.027 & 0.043 & -0.050 & $0.146^{* * *}$ \\
\hline SIZE & 0.039 & $-0.106^{* *}$ & 1.000 & 0.051 & -0.011 & $0.115^{* *}$ & 0.004 & 0.071 \\
\hline HORIZON & -0.023 & -0.045 & $0.087^{*}$ & 1.000 & 0.047 & -0.048 & -0.042 & 0.023 \\
\hline LNAGE & $-0.085^{*}$ & -0.077 & -0.021 & 0.052 & 1.000 & 0.068 & $0.119^{* *}$ & $-0.174^{\star * *}$ \\
\hline LEVERAGE & -0.027 & $0.119^{* *}$ & -0.002 & 0.000 & $-0.081^{*}$ & 1.000 & $0.133^{* * *}$ & $-0.231^{* * *}$ \\
\hline OWNERSHIP & -0.035 & $-0.140 * * *$ & -0.041 & -0.073 & $0.083^{*}$ & -0.078 & 1.000 & $-0.377^{* * *}$ \\
\hline$N M$ & $0.100^{* *}$ & $0.292^{* * *}$ & $0.203^{* * *}$ & 0.016 & $-0.188^{\star * *}$ & -0.051 & $-0.331^{* * *}$ & 1.000 \\
\hline
\end{tabular}

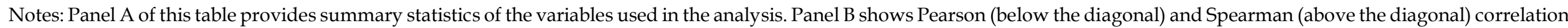

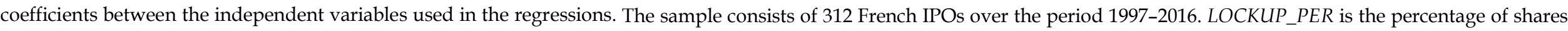

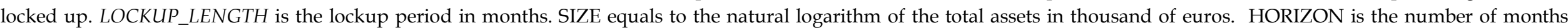

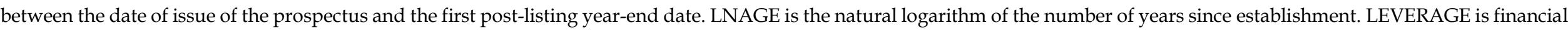

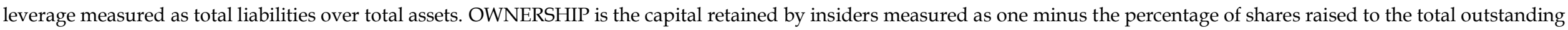
shares. NM is a dummy variable set to one if the firm's IPO is on the Nouveau Marché, and zero otherwise.

*** Significant at the $1 \%$ level

** Significant at the $5 \%$ level

* Significant at the $10 \%$ level 
Table 4. Descriptive statistics of forecast errors

\begin{tabular}{lcc}
\hline Range in percentage & Number & Percentage \\
\hline FE $>0.1$ & 71 & 22.76 \\
$0.0<$ FE $\leq 0.1$ & 164 & 4.56 \\
$-0.1<$ FE $\leq 0.0$ & 14 & 20.19 \\
FE $\leq-0.1$ & 63 & 100 \\
Total & 312 & \\
Mean & & \\
Median & & \\
\hline Notes: This table presents the descriptive statistics of forecast errors. & \\
\hline
\end{tabular}


Table 5. Logistic regression of voluntary forecast diclosure

\begin{tabular}{lcc}
\hline Variables & Coefficient & t-statistic \\
\hline INTERCEPT & $-3.8989 \mathrm{~d}$ & $4.40^{* * *}$ \\
SIZE & 0.1821 & $3.51^{* * *}$ \\
HORIZON & -0.0326 & -0.77 \\
LNAGE & 0.2062 & $1.75^{*}$ \\
LEVERAGE & -0.1515 & -0.88 \\
OWNERSHIP & 1.7586 & $2.69^{* * *}$ \\
NM & 1.1896 & $3.69^{* * *}$ \\
INDUSTRY & Yes & Yes \\
YEARS & Yes & Yes \\
Observations & & 513 \\
Pseudo R & & $0.1282^{* * *}$
\end{tabular}

Notes: This table presents the estimation results from the logistic regression of voluntary earnings forecast disclosure on its determinants. The dependent variable is FORECAST which takes one if the IPO firm provides an earnings forecast in its IPO prospectus and 0 otherwise. SIZE equals to the natural logarithm of the total assets in thousand of euros. HORIZON is the number of months between the date of issue of the prospectus and the first post-listing year-end date. LNAGE is the natural logarithm of the number of years since establishment. LEVERAGE is financial leverage measured as total liabilities over total assets. OWNERSHIP is the capital retained by insiders measured as one minus the percentage of shares raised to the total outstanding shares. NM is a dummy variable set to one if the firm's IPO is on the Nouveau Marché, and zero otherwise. Industry dummies and year dummies are included but not reported in the table.

*** Significant at the $1 \%$ level

* Significant at the $10 \%$ level. 
Table 6. OLS regression results of FE

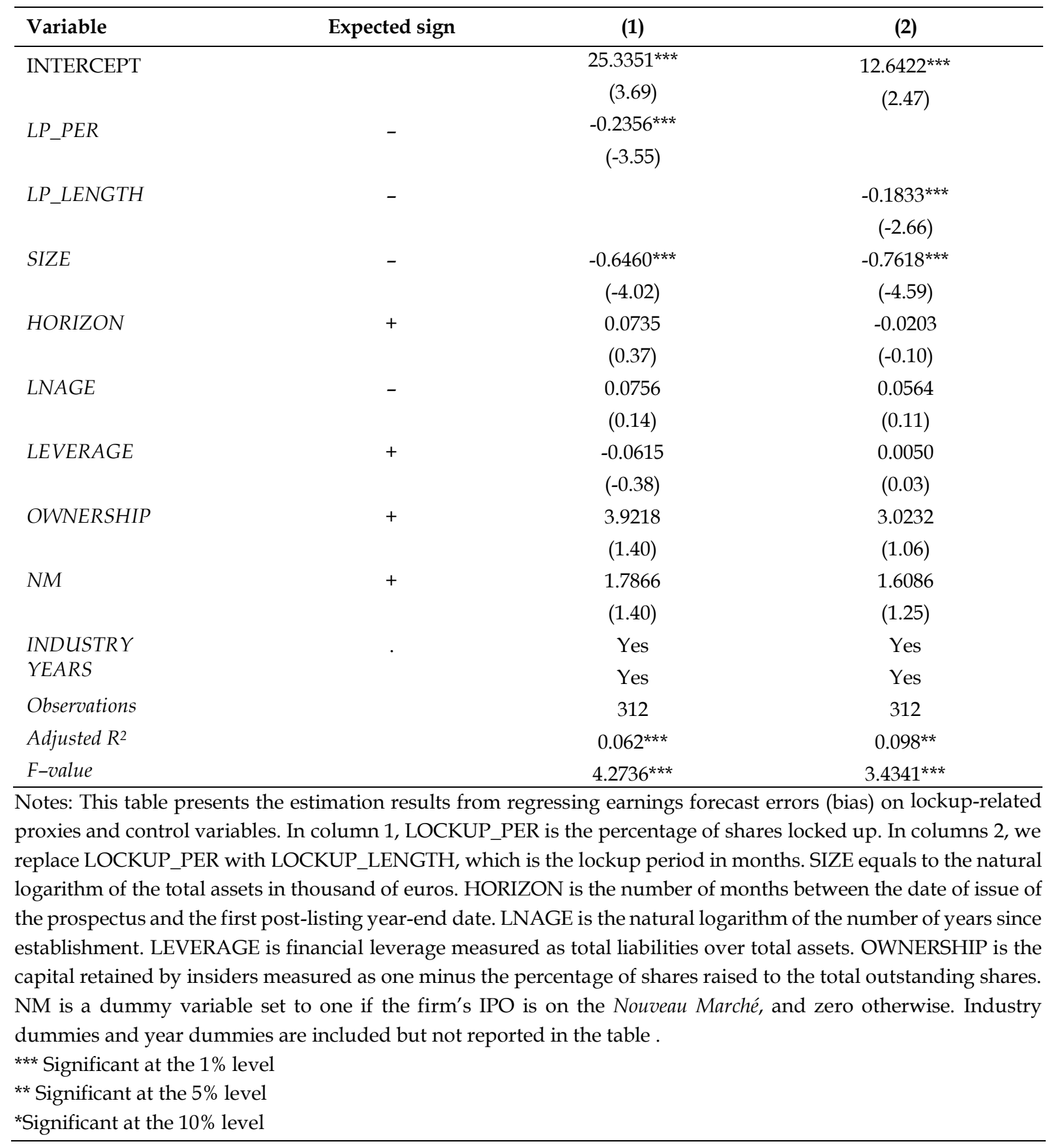


Table 7. OLS regression results of AFE

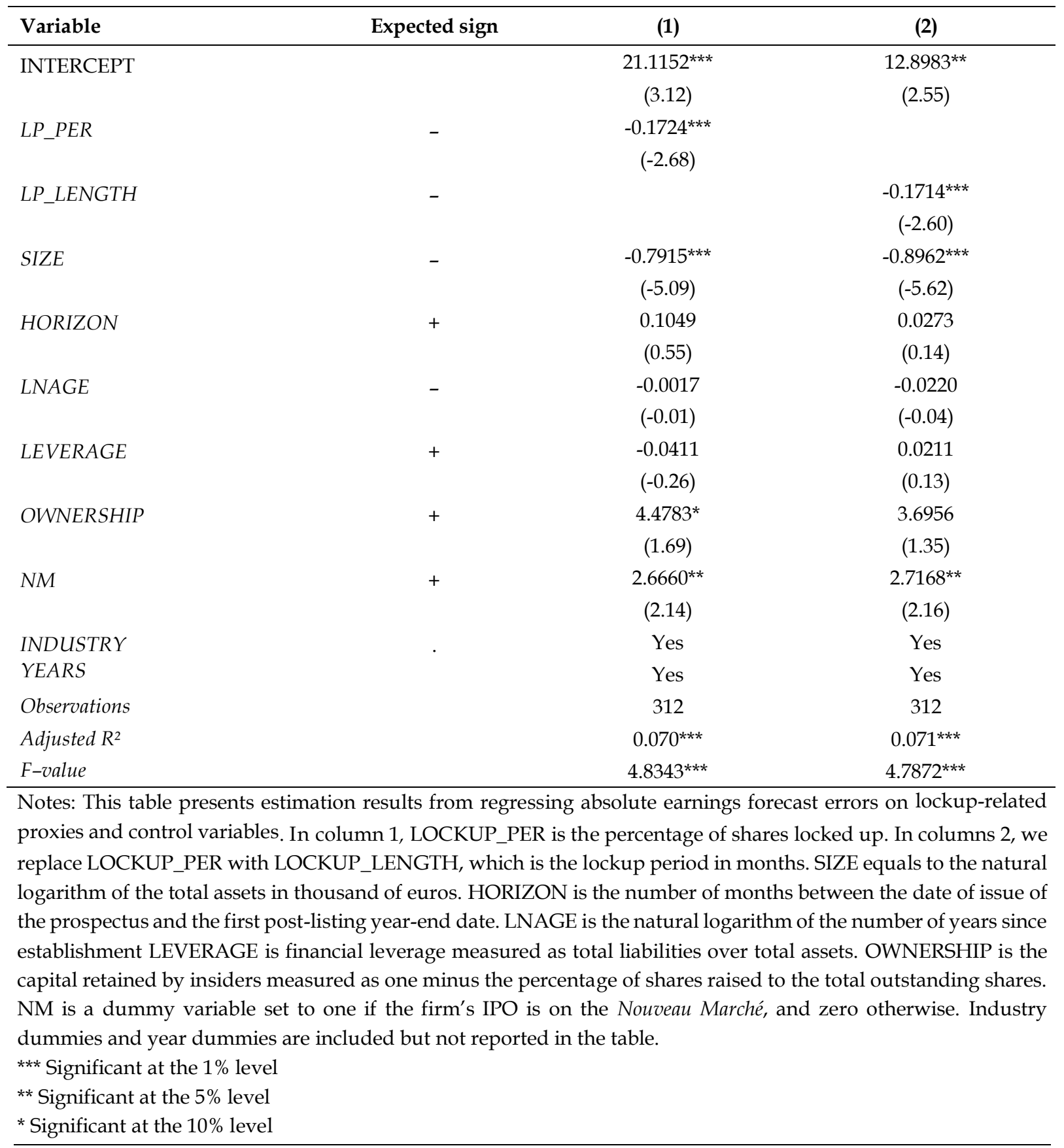


Table 8. Heckman selection model

\begin{tabular}{|c|c|c|c|c|}
\hline \multicolumn{2}{|c|}{$\begin{array}{l}\text { Stage-one : } \\
\text { FORECAST }\end{array}$} & \multicolumn{3}{|c|}{$\begin{array}{c}\text { Stage-two : } \\
\text { AFE }\end{array}$} \\
\hline INTERCEPT & $\begin{array}{c}-7.6182 * * * \\
(-6.7942)\end{array}$ & INTERCEPT & $\begin{array}{c}0.2352^{* * *} \\
(4.1599)\end{array}$ & $\begin{array}{r}0.1405^{* * *} \\
(4.2484)\end{array}$ \\
\hline LP_LENGTH & $\begin{array}{c}0.2358^{* * *} \\
(4.3095)\end{array}$ & LP_PER & $\begin{array}{l}-0.0017^{* * *} \\
(-2.7469)\end{array}$ & \\
\hline SIZE & $\begin{array}{c}0.1334^{* * *} \\
(2.9044)\end{array}$ & LP_LENGTH & & $\begin{array}{c}-0.0017^{* * *} \\
(-2.7040)\end{array}$ \\
\hline HORIZON & $\begin{array}{c}0.0461 \\
(1.3011)\end{array}$ & SIZE & $\begin{array}{c}-0.0078^{* * *} \\
(-5.3142)\end{array}$ & $\begin{array}{l}-0.0087^{* * *} \\
(-5.7976)\end{array}$ \\
\hline LNAGE & $\begin{array}{c}0.1081 \\
(1.2127)\end{array}$ & HORIZON & $\begin{array}{c}0.0010 \\
(0.5244)\end{array}$ & $\begin{array}{c}0.0002 \\
(0.0943)\end{array}$ \\
\hline LEVERAGE & $\begin{array}{l}1.1535^{*} \\
(1.8013)\end{array}$ & LNAGE & $\begin{array}{c}-0.0008 \\
(-0.1728)\end{array}$ & $\begin{array}{c}-0.0008 \\
(-0.1680)\end{array}$ \\
\hline OWNERSHIP & $\begin{array}{c}1.8449^{* * *} \\
(3.5375)\end{array}$ & LEVERAGE & $\begin{array}{c}-0.0004 \\
(-0.2674)\end{array}$ & $\begin{array}{c}0.0002 \\
(0.1171)\end{array}$ \\
\hline NM & $\begin{array}{c}9.4184 \\
(0.0003)\end{array}$ & OWNERSHIP & $\begin{array}{l}0.0453^{*} \\
(1.7341)\end{array}$ & $\begin{array}{c}0.0378 \\
(1.4430)\end{array}$ \\
\hline $\begin{array}{c}\text { INDUSTRY } \\
\text { YEARS }\end{array}$ & $\begin{array}{l}\text { Yes } \\
\text { Yes }\end{array}$ & NM & $\begin{array}{l}0.0257^{* *} \\
(2.1871)\end{array}$ & $\begin{array}{l}0.0256^{* *} \\
(2.1774)\end{array}$ \\
\hline & & LAMBDA & $\begin{array}{l}0.0749 * * \\
(2.4311)\end{array}$ & $\begin{array}{l}0.0762^{* *} \\
(2.5174)\end{array}$ \\
\hline & & $\begin{array}{l}\text { INDUSTRY } \\
\text { YEARS }\end{array}$ & $\begin{array}{l}\text { Yes } \\
\text { Yes }\end{array}$ & $\begin{array}{l}\text { Yes } \\
\text { Yes }\end{array}$ \\
\hline Log likelihood & & & 208.46 & 208.34 \\
\hline Wald Chi2 & & & 39.81 & 39.56 \\
\hline Observations & 513 & & 312 & 312 \\
\hline
\end{tabular}

The table reports the regression results using Heckman's (1979) two-stage selection model. In the first stage, the earnings forecast disclosure (FORECAST) is explained using a probit model. FORECAST is a dummy variable that takes the value 1 when the firm provides earnings forecast in its IPO prospectus and 0 otherwise. In the second stage, we include the inverse Mills ratio to control for potential sample selection problem in our baseline equation. We estimate two specifications where the dependent variable is the absolute forecast errors AFE. The variable of interest is LOCKUP_PER (first specification) and LOCKUP_LENGTH (second specification). LOCKUP_PER is the percentage of shares locked up. LOCKUP_LENGTH is the lockup period in months. The control variables are the following: SIZE equals to the natural logarithm of the total assets in thousand of euros. HORIZON is the number of months between the date of issue of the prospectus and the first post-listing year-end date. LNAGE is the natural logarithm of the number of years since establishment. LEVERAGE is financial leverage measured as total liabilities over total assets. OWNERSHIP is the capital retained by insiders measured as one minus the percentage of shares raised to the total outstanding shares. NM is a dummy variable set to one if the firm's IPO is on the Nouveau Marché, and zero otherwise. Industry dummies and year dummies are included but not reported in the table.

*** Significant at the $1 \%$ level

** Significant at the $5 \%$ level

*Significant at the $10 \%$ level 
Table 9. Sensitivity tests

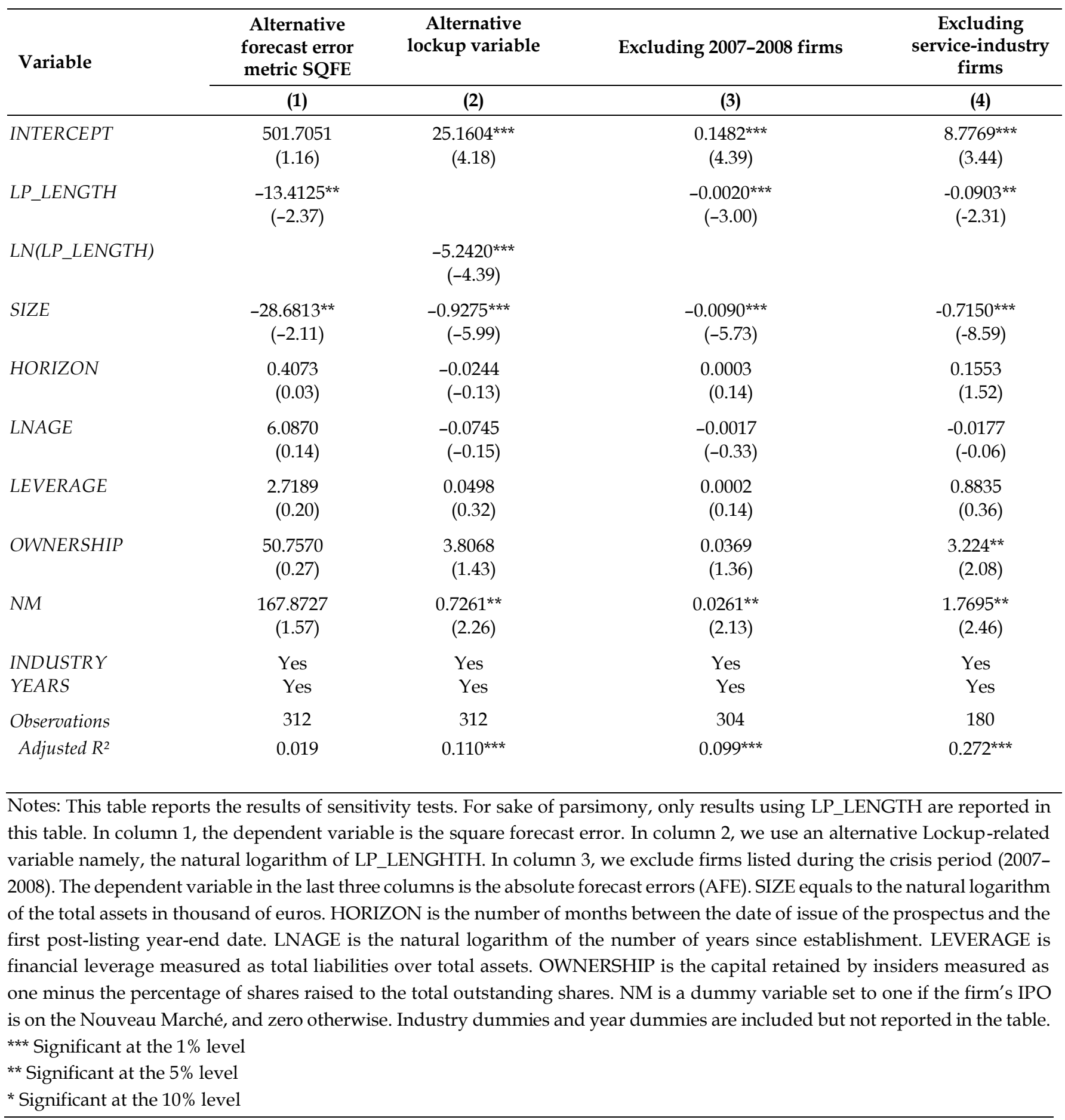

